\title{
The period of insect research in the tropics: a bibliometric analysis
}

\author{
M. C. Moshobane ${ }^{1,2}$ (D) T. T. Khoza ${ }^{1}$ (D) S. Niassy ${ }^{3}$ (D)
}

Received: 7 June 2021 / Accepted: 29 July 2021 / Published online: 9 September 2021

(c) African Association of Insect Scientists 2021

\begin{abstract}
The International Journal of Tropical Insect Science (Int J Trop Insect Sci) is a peer-reviewed journal established in 1980 to promote insect science mainly in the tropics. This study aimed to provide a Bibliometric overview of Int J Trop Insect Sci publications and citations between 2012 and 2020, ending September 2020. A sample of 488 documents extracted from the Web of Science (WoS) was analysed using widely used bioclimatic indicators. The articles were written by 1726 authors. During this period, the most productive authors comprised S Roy, followed by S Ekesi, S Subramanian and M Tamo. The dominant keyword was 'resistance', followed by 'Homoptera'. India took a leading position in Single Country Publications (SCP) while Kenya took the lead in Multiple Country Publications (MCP). Bibliometric analysis reveals vibrant collaboration between African and Western countries and active publication of multi-country authored articles. We conclude that there is an increasing trend for collaboration among different countries on the general topic of insect science. Research in insect science has the potential to impact both academic researchers and practitioners the knowledge use chain. This study will help researchers, journal editors, science policy makers managers, and others working in the biodiversity space and potential research gaps needing for further studies.
\end{abstract}

Keywords Bibliometric analysis $\cdot$ Scientific collaboration $\cdot$ Bibliometric Citation analysis $\cdot$ Publication analysis

\section{Introduction}

Insects are one of the most diverse group of animals with over a million described species representing 75 percent of the world's documented fauna (Stork 1999; Engel and Grimaldi 2004; Grimaldi and Engel 2005). They also display a greater diversity, especially in the tropics (Engel and Grimaldi 2004; Grimaldi and Engel 2005). Furthermore, insects are central to human livelihoods both as friends and foes (Snow et al. 1999; van Huis 2003).

The International Journal of Tropical Insect Science (Int J Trop Insect Sci) is a peer-reviewed journal established in 1980 to promote insect science mainly in the tropics

M. C. Moshobane

moshobanemc@gmail.com

1 South African National Biodiversity Institute, Pretoria National Botanical Garden, 2 Cussonia AvenuePrivate Bag X101, Brummeria, PretoriaSilverton 0184, South Africa

2 Department of Biology, Sefako Makgatho Health Sciences University, Ga-Rankuwa, South Africa

3 International Centre of Insect Physiology and Ecology (Icipe), Nairobi, Kenya
(McKelvey 1980; Odhiambo 1980). The journal's first impact factor was 0.419 (Kelemu 2015), and in 2019 it achieved a five-year impact factor of 0.748 . The journal was ranked 76 out of 92 journals in entomology in the InCites $^{\mathrm{TM}}$ Journal Citation Reports ${ }^{\circledR}$ (JCR) of the Web of Science $^{\mathrm{TM}}$ (Kelemu 2015) and is ranked 87 out of 101 journals in the entomology category. The journal publishes all aspects of insect science, such as pest and vector management research (McKelvey 1980; Odhiambo 1980). It stands out in its multi-disciplinary approach that covers a broad spectrum of disciplines including environmental physiology; regulation of development and production; population modelling; chemical ecology; natural products chemistry; plant resistance; host/insect relations; behaviour of tropical pest species; epidemiology of tropical diseases; vector biology; pest and vector management; ento-meteorology; insects in relation to farming systems; forest entomology; insect pathology; social insects and arthropods; and uses of insects (Odhiambo 1980). At present the journal is indexing in most of the prestigious journal databases. Since the establishment of the International Journal of Tropical Insect Science, there has been little or no studies to assess the journal's impact in generating new knowledge 
continent-wide and globally. Despite its relevance, there has been little effort to assess the quality of science and the knowledge structure and such studies are essential to indicate the gaps.

Bibliometric analysis is a literature review method that statistically and quantitatively analyses published studies (Broadus 1987) and has received a lot of attention (Liang and Liu 2018). Bibliometric analysis is useful for examining the knowledge structure and development of specific research fields (Ellegaard and Wallin 2015). Recently, this approach has enabled researchers to comprehensively quantify and delineate the most prolific researchers, institutions, because the approach is deemed to be more objective and reliable than other common methods of literature review techniques (Aria and Cuccurullo 2017). The strength of bibliometrics relies on robust transparency and reproducibility (Aria and Cuccurullo 2017). Bibliometrics includes several descriptive statistics of citation data and network analysis of authors, journals, universities, countries, and keywords based on citations and frequency analysis techniques. Bibliometrics supports the identification of research clusters, provides insights into current research interests, and reveals trends for emerging topics in a field. Therefore, this study adopts a bibliometric approach to systematically evaluate the vast literature published over 9 years (2012-2020, ending September 2020) in the International Journal of Tropical Insect Science.

\section{Materials and methods}

To collect relevant bibliography data from the International Journal of Tropical Insect Science, a keyword search ("International Journal of Tropical Insect Science") was performed in October 2020 on the Web of Science (WoS, http://www. webofknowledge.com) academic database. Publication records for 9 years, from 2012 to September 2020, were retrieved from the International Journal of Tropical and Insect Science.

All analyses on the collected bibliography data were conducted using the open-source R programming software called Bibliometrix 3.0. Co-citation analysis, bibliographic coupling, and keyword co-occurrence (van Eck and Waltman 2010; Zupic and Čater 2015) were performed.

Although Bibliometrix offers a few alternatives, the multi-dimensional scaling (MDS) method (Tzeng et al. 2008) was selected for information visualisation and the Louvain clustering algorithm (Blondel et al. 2008) was selected to detect communities in networks. The Louvain clustering algorithm allows networks of unprecedented size to be accessible to computational analysis and outperforms all the other methods of computation time, memory-efficient manner, and quality of the communities detected (Blondel et al. 2008). The bibliographic coupling approach, introduced by Kessler (1963), was used to identify the underlying research cluster and map contemporary research developments. When two or more published studies share at least one common citation, they are bibliographically coupled (Kessler 1963). Lotka's Law, a bibliometric measure of authorship concentration that describes the authors' frequency of scientific publication, was also used.

In cluster analysis, normalisation approaches compensate for different occurrence levels among items, and MDS also benefits from normalisation (Tzeng et al. 2008). Thus, the bibliographic coupling data was normalised using the 'association' measure (van Eck and Waltman 2010).

\section{Results and discussion}

\section{Scientific production}

Over 488 research products were produced in the International Journal of Tropical Insect Science between 2012 and September 2020 from 1653 authors, with an average citation per document of 1.885 . All documents were published in English; at least 1726 authors participated in the publication of the retrieved papers. Therefore, the minimum average number of authors per paper was 1.7.

The annual production of scientific papers was found to fluctuate, with 2020 seeming to be the most productive year, despite the records ending in September 2020 (Fig. 1). This could be attributed to global lockdowns for COVID-19, when the scientific community potentially had time to process the scientific backlog of papers and manuscripts (Müller et al. 2020). Other reasons could be the growing impact of research published by the International Journal of Tropical Insect Science, a trend that was noted by Kelemu (2015) back in 2015 . Furthermore, the transition from manual submission system with Cambridge University Press to online under Springer Nature Switzerland AG may have contributed to the increase. Out of the 488 papers, 451 (93.6\%) were original research papers, and $14(2.8 \%)$ were review papers.

\section{Top cited papers}

The top 10 cited papers in the International Journal of Tropical Insect Science 2012-2020 were considered. The papers have citations ranging from 10 to 25 and a citation average ranging from 1.6 to 3 per year. Nine (9) of the most cited papers are full research publications, and 1 was a review paper by Saha and Mukhopadhyay (2013). The study by Lezama-Gutiérrez et al. (2012), which used 
Fig. 1 Total number of papers published in International Journal of Tropical Insect Science per year

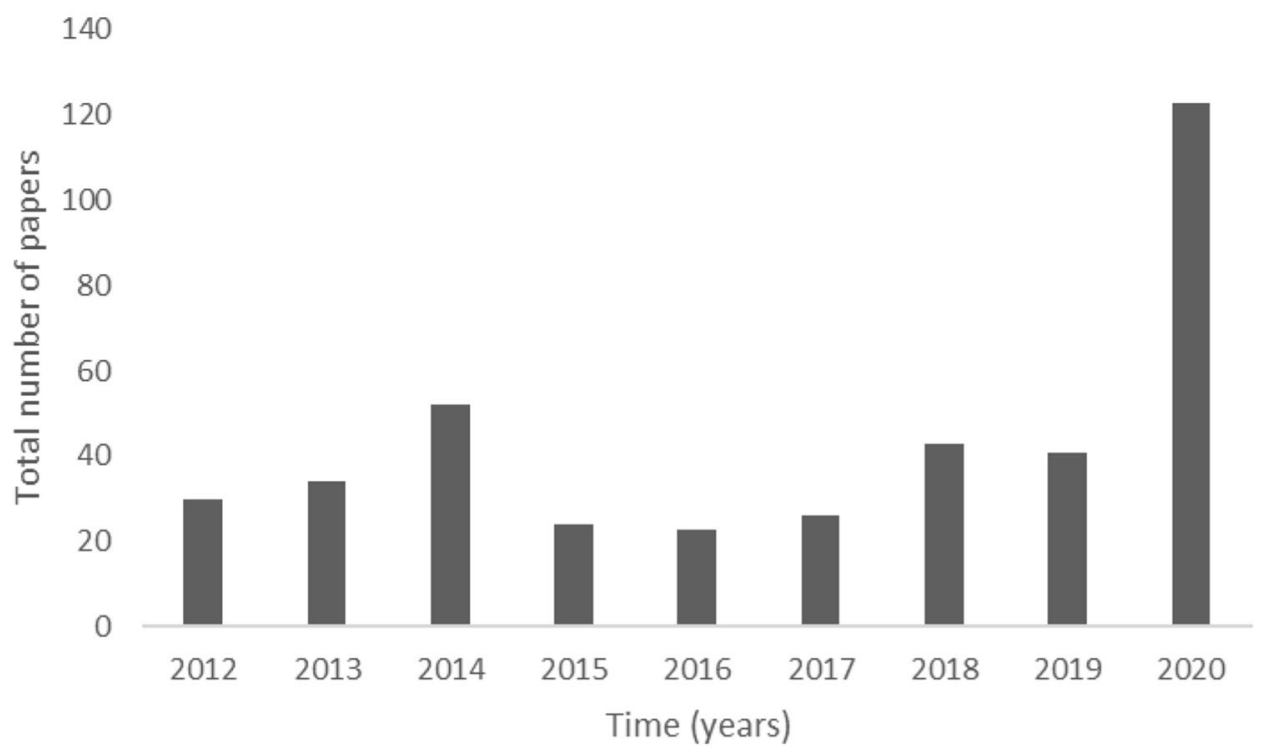

entomopathogenic fungi as biocontrol agents, received the highest citations. The second most highly cited paper is by Saha and Mukhopadhyay (2013), where they reviewed a paper on insecticide resistance (Table 1); moreover, the most cited paper of the journal since inception is a review of uses of insects for food by van Huis (2003) with over 200 citations; however, this paper was outside of the range of the study.

The present study only investigated the recent 9 years, and this is reflected in the citation index of papers, which is only expected to increase with time (Bartneck and Kokkelmans 2011). The 10 most cited papers were published within the first 4 years of the study period (Table 1), as envisaged by McKelvey (1980). It is reported that citations accumulate with time, and papers published earlier have a higher probability of receiving more citations than recent publications, making this an important issue when the citation count is used for ranking of individual papers (Bartneck and Kokkelmans 2011). Intra-Africa collaborations are also encouraged in order to develop regional capacity (Asubiaro 2019).

\section{Most productive authors}

The 20 most productive authors were considered (Table 2). The most productive author over the 9 years study period was Somnath Roy, who penned 11 papers, followed by Sunday Ekesi, Sevgan Subramanian, and Manuele Tamo, with 9 papers each. The first paper by Somnath Roy was published in 2012, titled "insecticide susceptibility and activity of major detoxifying enzymes in female Helopeltis theivora (Heteroptera: Miridae) from sub-Himalayan tea plantations of North Bengal, India" by S Roy and colleagues (Saha et al. 2012), and the more recent paper was first published online in October 2020, titled "Biodiversity of soil arthropods with emphasis on oribatid mites in three different tea agro-ecosystem with three different agronomical practices in Assam, India" (Roy et al. 2020). The first paper by Sunday Ekesi titled "Effect of fungicides used for powdery mildew disease management on the African weaver ant, Oecophylla longinoda (Hymenoptera: Formicidae), a biocontrol agent of sap-sucking pests in cashew crops in Tanzania" (Olotu et al. 2013) was published in 2013. A more recent paper was published in August 2020, titled "The African citrus triozid Trioza erytreae Del Guercio (Hemiptera: Triozidae): Temporal dynamics and susceptibility to entomopathogenic fungi in East Africa" (Aidoo et al. 2020). Sevgan Subramanian's first paper appeared in 2014 titled, "Resistance to Iris yellow spot virus and onion thrips among onion varieties grown in Kenya" (Birithia et al. 2014), and the latest paper in 2017 was titled "Impact of introduced parasitoid Cotesia vestalis (Hymenoptera: Braconidae) on Plutella xylostella (Lepidoptera: Plutellidae) and its parasitoid guild on kale in semi-arid areas in Kenya" (Kahuthia-Gathu et al. 2017). Lastly, the papers by Manuele Tamo first appeared in 2012 titled, "Interaction between the aphid parasitoid Lysiphlebus testaceipes (Hymenoptera: Aphidiidae) and its hyperparasitoid Syrphophagus africanus (Hymenoptera: Encyrtidae)" (Ganyo et al. 2012), and the latest paper appeared in August 2020 titled, "Bioactivity of essential oils of Cymbopogon citratus (DC) Stapf and Cymbopogon nardus (L.) W. Watson from Benin against Dinoderus porcellus Lesne (Coleoptera: Bostrichidae) infesting yam chips" (Loko et al. 2020). 
Table 1 Top 10 cited papers in the International Journal of Tropical Insect Science, as extracted from the WOS ( $\mathrm{n}=488)$ during the period from 2012 to September 2020

\begin{tabular}{|c|c|c|c|c|}
\hline Paper & Paper title & $\begin{array}{l}\text { Total } \\
\text { Citations }\end{array}$ & TC per Year & $\begin{array}{l}\text { Research focus according to Odhiambo } \\
(1980)\end{array}$ \\
\hline (Lezama-Gutiérrez et al. 2012) & $\begin{array}{l}\text { Use of the entomopathogenic fungi } \\
\text { Metarhizium anisopliae, Cordyceps } \\
\text { bassiana and Isaria fumosorosea to } \\
\text { control Diaphorina citri (Hemiptera: } \\
\text { Psyllidae) in Persian lime under field } \\
\text { conditions }\end{array}$ & 25 & 2.778 & Pest and vector management research \\
\hline (Saha and Mukhopadhyay 2013) & $\begin{array}{l}\text { (Review Paper) Insecticide resistance } \\
\text { mechanisms in three sucking insect } \\
\text { pests of tea with reference to North- } \\
\text { East India: An appraisal }\end{array}$ & 21 & 2.625 & Host/insect relations \\
\hline (Muvea et al. 2014) & $\begin{array}{l}\text { Attraction of pest thrips (Thysanoptera: } \\
\text { Thripidae) infesting French beans to } \\
\text { coloured sticky traps with Lurem-TR } \\
\text { and its utility for monitoring thrips } \\
\text { populations }\end{array}$ & 21 & 3 & Pest and vector management research \\
\hline (Musundire et al. 2014) & $\begin{array}{l}\text { Nutrient and anti-nutrient composition } \\
\text { of Henicus whellani (Orthoptera: Sten- } \\
\text { opelmatidae), an edible ground cricket, } \\
\text { in south-eastern Zimbabwe }\end{array}$ & 20 & 2.857 & Uses of insects \\
\hline (Edoh Ognakossan et al. 2013) & $\begin{array}{l}\text { Post-harvest insect infestation in maize } \\
\text { grain stored in woven polypropylene } \\
\text { and in hermetic bags }\end{array}$ & 19 & 2.375 & Insects in relation to farming systems \\
\hline (Adu-Acheampong et al. 2014) & $\begin{array}{l}\text { Multi-Institutional Study The cocoa } \\
\text { mirid (Hemiptera: Miridae) problem: } \\
\text { Evidence to support new recommen- } \\
\text { dations on the timing of insecticide } \\
\text { application on cocoa in Ghana }\end{array}$ & 14 & 2 & Pest and vector management research \\
\hline (Ahmad et al. 2013) & $\begin{array}{l}\text { Acute toxicity and sublethal effects of } \\
\text { the neonicotinoid imidacloprid on the } \\
\text { fitness of Helicoverpa armigera (Lepi- } \\
\text { doptera: Noctuidae) }\end{array}$ & 13 & 1.625 & Pest and vector management research \\
\hline (Vera et al. 2014) & $\begin{array}{l}\text { Development of a larval diet for the } \\
\text { South American fruit fly Anastrepha } \\
\text { fraterculus (Diptera: Tephritidae) }\end{array}$ & 13 & 1.857 & Vector biology \\
\hline (Tumuhaise et al. 2015) & $\begin{array}{l}\text { Pathogenicity and performance of two } \\
\text { candidate isolates of Metarhizium } \\
\text { anisopliae and Beauveria bassiana } \\
\text { (Hypocreales: Clavicipitaceae) in four } \\
\text { liquid culture media for the manage- } \\
\text { ment of the legume pod borer Maruca } \\
\text { vitrata (Lepidoptera: Crambidae) }\end{array}$ & 13 & 2.167 & Natural products chemistry \\
\hline (Korir et al. 2015) & $\begin{array}{l}\text { Grower adoption of an integrated pest } \\
\text { management package for management } \\
\text { of mango-infesting fruit flies (Diptera: } \\
\text { Tephritidae) in Embu, Kenya }\end{array}$ & 13 & 2.167 & Pest and vector management research \\
\hline
\end{tabular}

\section{Co-authorship}

Co-authorship is one factor considered in evaluating scientific collaboration among researchers, institutions, and countries (Tabatabaei-Malazy et al. 2016). A co-authorship country network map was created using the R package Bibliometrix 3.0. (Aria and Cuccurullo 2017), with a minimum number of documents for a country set at 5 . The dominant countries are India, Kenya, the USA, and China (Figs. 2 and 3). There were co-author connections between the USA and 4 African countries, while Kenya had coauthor connections with Tanzania, Germany, France, and Uganda (Fig. 3). A robust collaborative link was observed between South Africa and the USA, based on the closeness of the nodes or circles and the thickness of the connecting lines on the map (Fig. 3). 
Table 2 The top 20 most productive authors in the International Journal of Tropical Insect Science, 2012-2020

\begin{tabular}{lll}
\hline Authors & Articles & Fractionalized \\
\hline ROY S & 11 & 2.32 \\
EKESI S & 9 & 1.84 \\
SUBRAMANIAN S & 9 & 1.88 \\
TAMO M & 9 & 1.39 \\
KUMAR S & 7 & 1.89 \\
SAHA D & 7 & 3.25 \\
MANIANIA NK & 6 & 1.09 \\
MOHAMED SA & 6 & 1.11 \\
SRINIVASAN R & 6 & 1.09 \\
KHAMIS FM & 5 & 0.86 \\
OMKAR & 5 & 1.58 \\
BHARATI M & 4 & 1.42 \\
BORGEMEISTER C & 4 & 2.59 \\
CHANG CL & 4 & 0.98 \\
GOGI MD & 4 & 0.82 \\
GUPTA S & 4 & 1.17 \\
HANDIQUE G & 4 & 0.82 \\
MISHRA G & 4 & 1.25 \\
MUKHOPADHYAY A & 4 & 1.53 \\
PITTENDRIGH BR & 4 & 0.68 \\
\hline
\end{tabular}

The historiographic map is used to provide a chronological network map of direct citation (Garfield 2004). There was a disconnected evolution of direct citation from 2012 to 2020. We can identify 3 nodes: first, it evolved from Saha et al. (2012), then in 2014, a new node developed from Muvea et al. (2014) that persisted for 4 years until a recent node evolved from Bande-Borujeni et al. (2018) through to 2020 (Fig. 4).

The direction of current trends, as shown by keywords, provides an insight into future research directions (Ravikumar et al. 2015). There was a general growth in keywords from 2012 to 2020. Ten (10) common keywords (Figs. 5 and 6) were being frequently used, with the word "resistance" showing the most apparent growth followed by "Homoptera" (Fig. 5). For example, "resistance" is an important topic for the management of pests and other common weeds, and the research on resistance is concerned by insect resistance (Samal and Kumar 2020) to pesticides and plant resistance to insect herbivory (Baliddawa 1985; Makkar et al. 2019). The emergence of biological control and management as keywords is directly in line with the journal's objective, as set out by Odhiambo (1980).

\section{Collaborations}

Multiple country collaborations tend to create channels that facilitate knowledge dissemination and access to funding for organizations that may not afford high-end technology

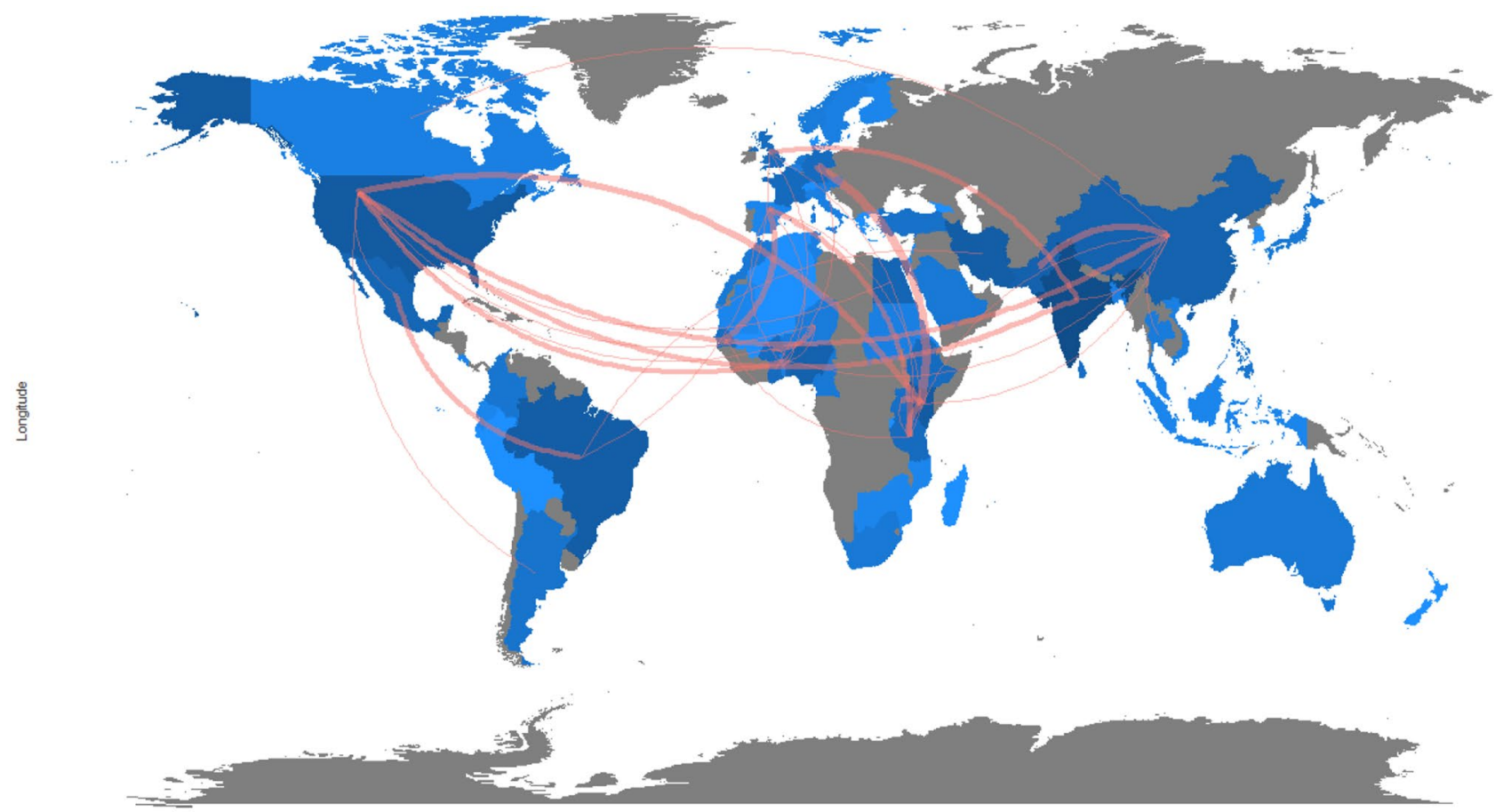

Fig. 2 Country network map based on country of affiliation of authors publishing in the International Journal of Tropical Insect Science, 20122020 
Fig. 3 Co-author network map showing linkages and collaboration between various countries

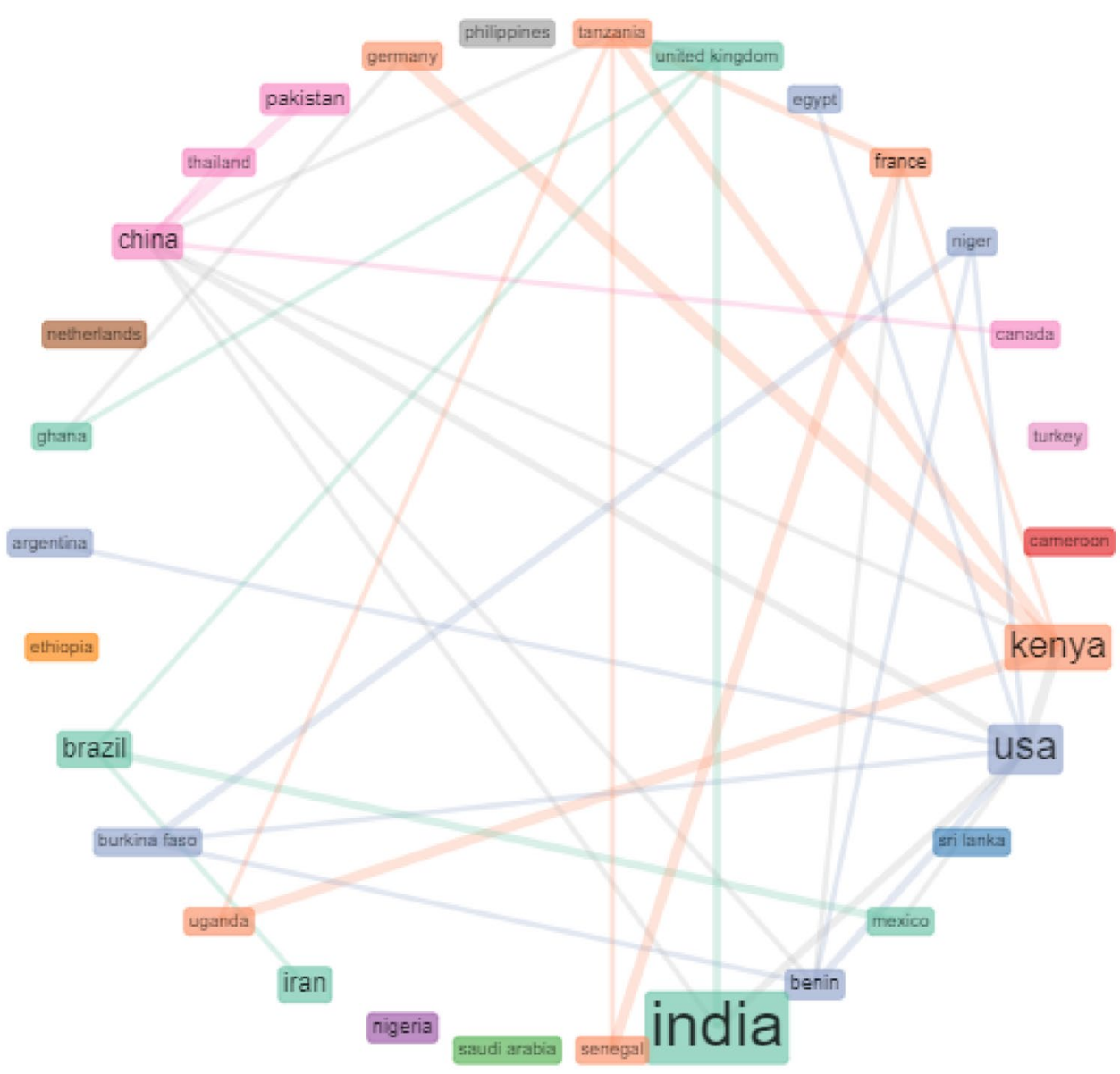

(Rawlings and McFarland 2011; Leone Sciabolazza et al. 2020). As a result, this increased knowledge dissemination improves the quality of the research outputs (Lee and Bozeman 2005; Abramo et al. 2009; Bikard et al. 2015;

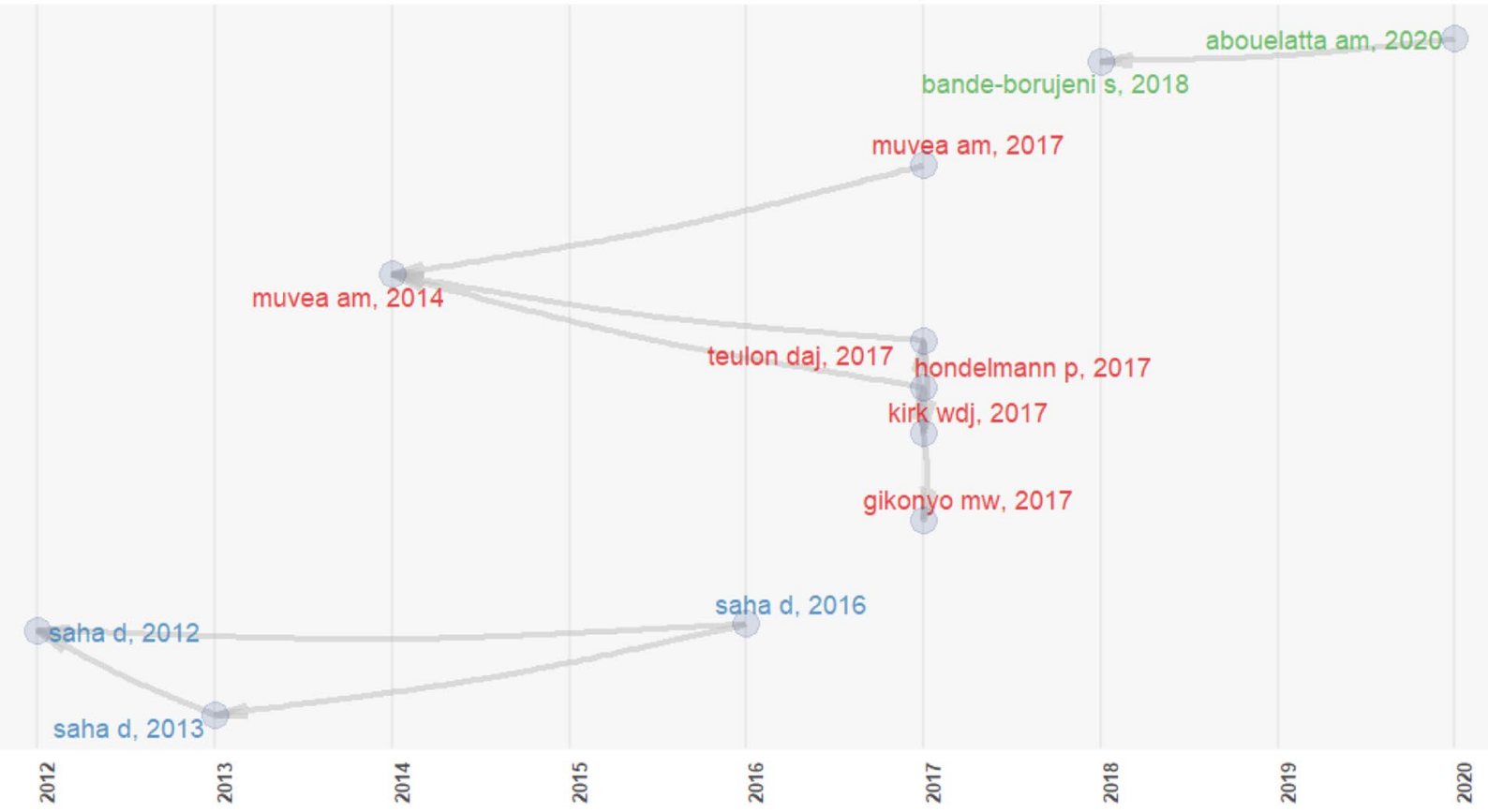

Fig. 4 Historiographical representation of direct citation networks 


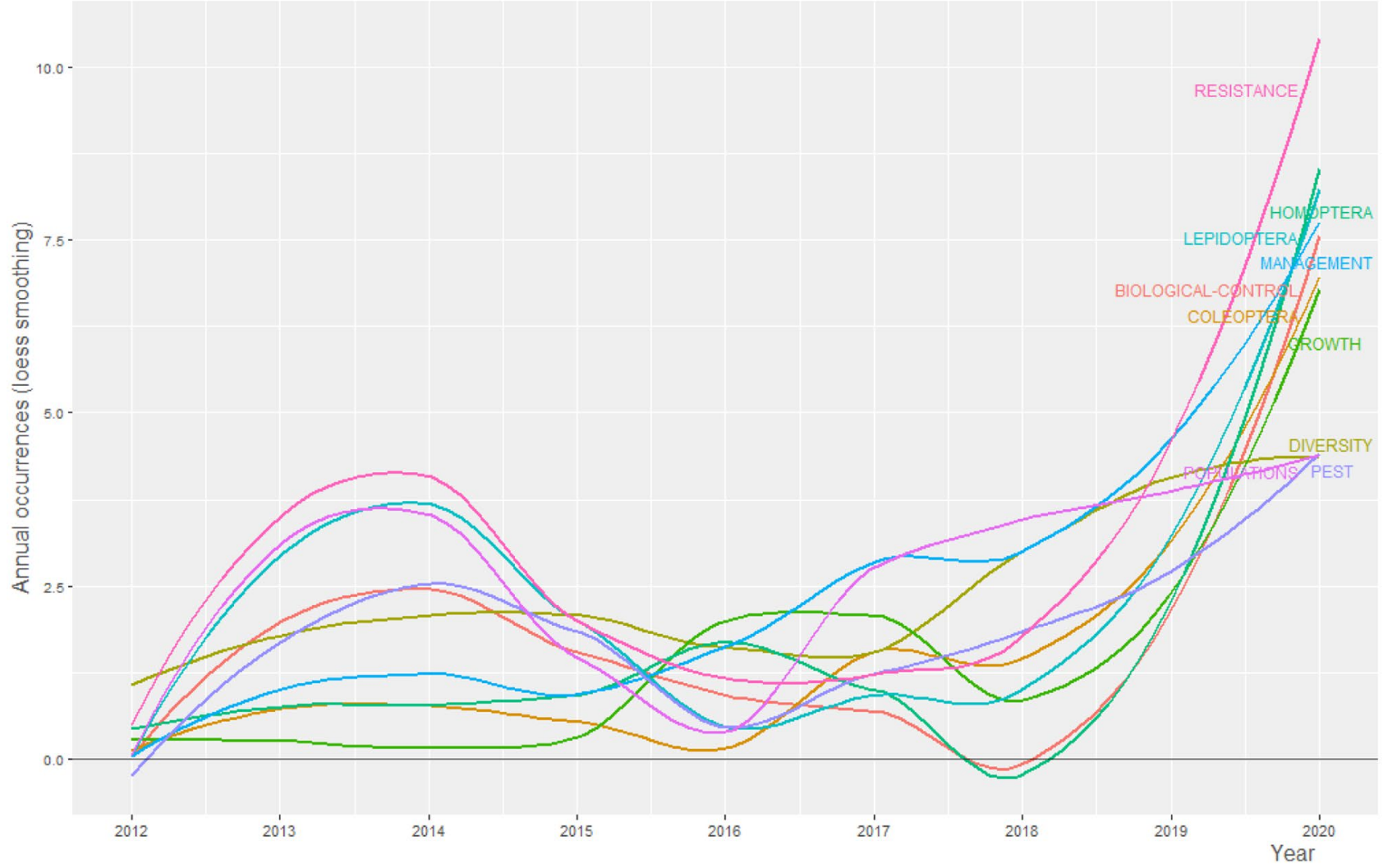

Fig. 5 Growth of keywords per year in the International Journal of Tropical Insect Science, 2012-2020

Ceballos et al. 2017). Although there are several ways for measuring collaboration, the common method is the use of research publication co-authorships (Ferligoj et al. 2015). Co-authorship is used because it is a sufficiently objective and straightforward way to gauge scientific cooperation.
Furthermore, Multiple Country Publications (MCP) is beneficial because papers have more citations than papers from Single Country Publications (SCP) (Prieto-Gutierrez and Segado-Boj 2019). We found that all papers from Germany are MCP, while papers from Colombia are SCP (Fig. 7).
Fig. 6 Wordcloud of keywords (max 50) from research published in the International Journal of Tropical Insect Science, 2012-2020

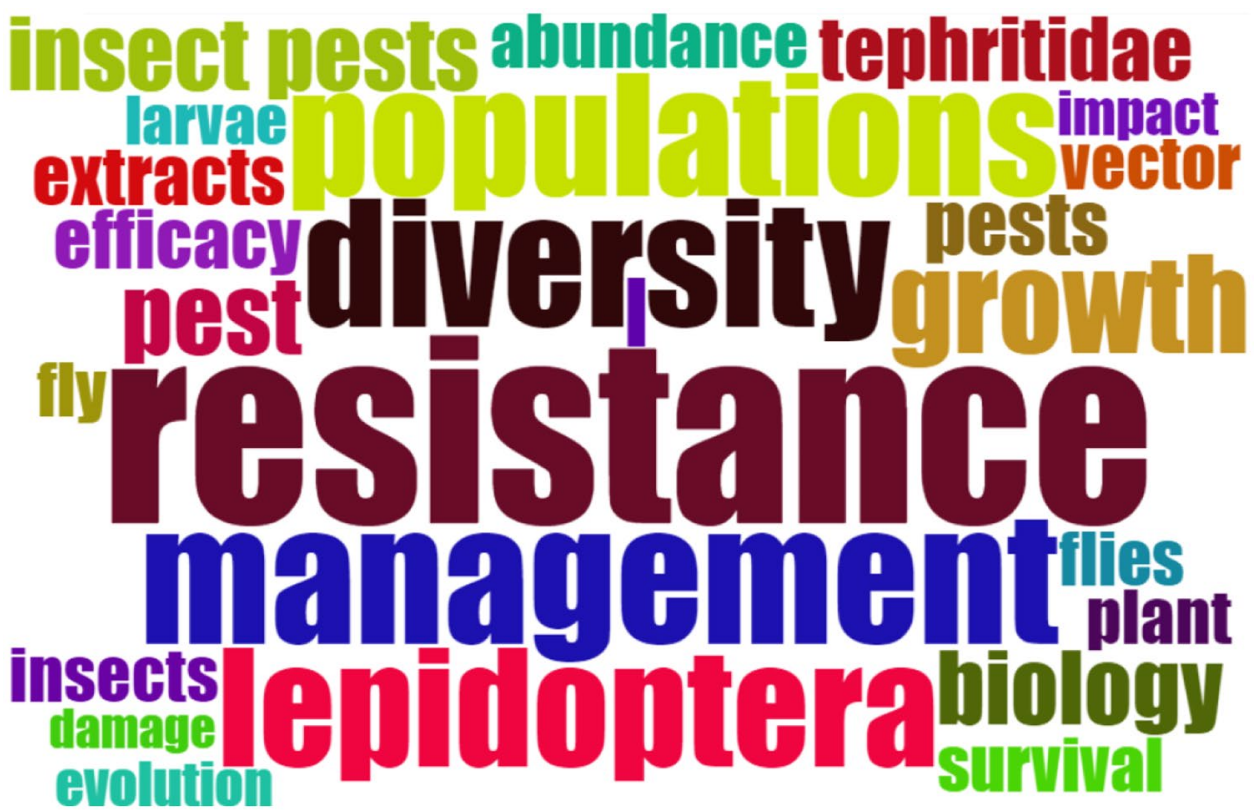


Fig. 7 The global contribution by country of corresponding author's country in the International Journal of Tropical Insect Science, 2012-2020. SCP $=$ Single country publications (SCP) and $\mathrm{MCP}=$ Multiple country publications (MCP)

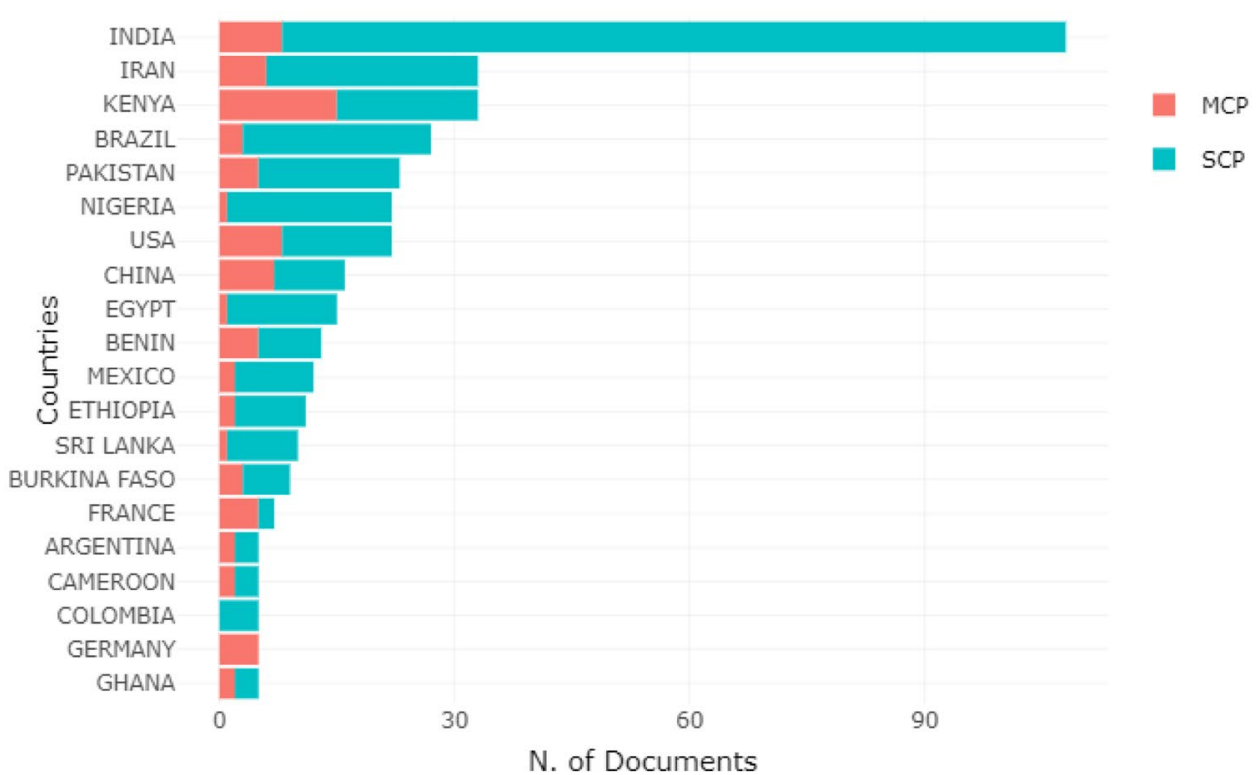

India and Iran were the most productive countries with SCP, and Kenya was the most productive with MCP (Fig. 7). There is an increase in multi-authored papers (Crase and Rosato 1992), a pattern observed across several areas of specialities (MacNeil 2019). This trend has a direct impact on the volume of MCP (Wagner and Leydesdorff 2005). In essence, this trend promotes MCP papers across all spectrums (Luukkonen et al. 1992).

\section{Conclusion}

This study aimed to give an overview of insect research articles published in the journal IJTIS, using publications from the International Journal of Tropical Insect Science as a case study. Bibliometric analysis is a statistical tool used to assess the quantity and quality of publications and the extent of success and achievements accomplished on a specific topic (Ellegaard and Wallin 2015). Bibliometric analysis reveals vibrant collaboration between African and Western countries and active publication of multicountry authored articles. Although there was research attention on biological control, which is somewhat branch of invasion biology, we feel that since the threat from invasive species is well established (Pyšek et al. 2020). The numbers are only increasing (Seebens et al. 2017); we recommend that future studies investigate the invasion from insects, particularly on the African continent, because of the projected influx and increase of invasive arthropods (Seebens et al. 2020). This increase may be attributed to climate change, which will benefit invasive arthropods such as Bemisia tabaci on the African continent (Mudereri et al. 2021).

Acknowledgements The South African The Department of Forestry, Fisheries and the Environment (DFFE) are thanked for funding, noting that this publication does not necessarily represent the views or opinions of DFFE or its employees. This work was supported by the South African National Biodiversity Institute.

\section{Declarations}

Disclaimer Any opinion, finding, and conclusion or recommendation expressed in this material is that of the author(s), and the funding agencies do not accept any liability in this regard.

\section{References}

Abramo G, D’Angelo CA, Di Costa F (2009) Research collaboration and productivity: is there correlation? High Educ 57:155-171. https://doi.org/10.1007/s10734-008-9139-Z

Adu-Acheampong R, Jiggins J, Van Huis A et al (2014) The cocoa mirid (Hemiptera: Miridae) problem: Evidence to support new recommendations on the timing of insecticide application on cocoa in Ghana. Int J Trop Insect Sci 34:58-71. https://doi.org/ $10.1017 / \mathrm{S} 1742758413000441$

Ahmad S, Ansari MS, Ahmad N (2013) Acute toxicity and sublethal effects of the neonicotinoid imidacloprid on the fitness of Helicoverpa armigera (Lepidoptera: Noctuidae). Int J Trop Insect Sci 33:264-275. https://doi.org/10.1017/S1742758413000246

Aidoo OF, Tanga CM, Mohamed SA et al (2020) The African citrus triozid Trioza erytreae Del Guercio (Hemiptera: Triozidae): temporal dynamics and susceptibility to entomopathogenic fungi in East Africa. Int J Trop Insect Sci. https://doi.org/10. 1007/s42690-020-00241-5 
Aria M, Cuccurullo C (2017) bibliometrix: An R-tool for comprehensive science mapping analysis. J Informetr 11:959-975. https:// doi.org/10.1016/j.joi.2017.08.007

Asubiaro T (2019) How collaboration type, publication place, funding and author's role affect citations received by publications from Africa: A bibliometric study of LIS research from 1996 to 2015. Scientometrics 120:1261-1287. https://doi.org/10.1007/ s11192-019-03157-1

Baliddawa CW (1985) Insect behaviour and host plant resistance. Int J Trop Insect Sci 6:337-340. https://doi.org/10.1017/ s1742758400004604

Bande-Borujeni S, Zandi-Sohani N, Ramezani L (2018) Chemical composition and bioactivity of essential oil from Eucalyptus occidentalis leaves against two stored product pests. Int J Trop Insect Sci 38:216-223. https://doi.org/10.1017/S1742758418000085

Bartneck C, Kokkelmans S (2011) Detecting h-index manipulation through self-citation analysis. Scientometrics 87:85-98. https:// doi.org/10.1007/s11192-010-0306-5

Bikard M, Murray F, Gans JS (2015) Exploring trade-offs in the organization of scientific work: Collaboration and scientific reward. Manage Sci 61:1473-1495. https://doi.org/10.1287/ mnsc. 2014.2052

Birithia RK, Subramanian S, Muthomi JW, Narla RD (2014) Resistance to Iris yellow spot virus and onion thrips among onion varieties grown in Kenya. Int J Trop Insect Sci 34:73-79. https://doi. org/10.1017/S1742758414000289

Blondel VD, Guillaume JL, Lambiotte R, Lefebvre E (2008) Fast unfolding of communities in large networks. J Stat Mech Theory Exp. https://doi.org/10.1088/1742-5468/2008/10/P10008

Broadus RN (1987) Toward a definition of 'bibliometrics.' Scientometrics 12:373-379. https://doi.org/10.1007/BF02016680

Ceballos HG, Fangmeyer J, Galeano N et al (2017) Impelling research productivity and impact through collaboration: A scientometric case study of knowledge management. Knowl Manag Res Pract 15:346-355. https://doi.org/10.1057/s41275-017-0064-8

Crase D, Rosato FD (1992) Single versus Multiple Authorship in Professional Journals. J Phys Educ Recreat Danc 63:28-32. https:// doi.org/10.1080/07303084.1992.10609913

Edoh Ognakossan K, Tounou AK, Lamboni Y, Hell K (2013) Postharvest insect infestation in maize grain stored in woven polypropylene and in hermetic bags. Int J Trop Insect Sci 33:71-81. https://doi.org/10.1017/S1742758412000458

Ellegaard O, Wallin JA (2015) The bibliometric analysis of scholarly production: How great is the impact? Scientometrics 105:18091831. https://doi.org/10.1007/s11192-015-1645-z

Engel MS, Grimaldi DA (2004) New light shed on the oldest insect. Nature 427:627-630. https://doi.org/10.1038/nature02291

Ferligoj A, Kronegger L, Mali F et al (2015) Scientific collaboration dynamics in a national scientific system. Scientometrics 104:9851012. https://doi.org/10.1007/s11192-015-1585-7

Ganyo KK, Kodjo Tounou A, Agboton C et al (2012) Interaction between the aphid parasitoid Lysiphlebus testaceipes (Hymenoptera: Aphidiidae) and its hyperparasitoid Syrphophagus africanus (Hymenoptera: Encyrtidae). Int J Trop Insect Sci 32:45-55. https://doi.org/10.1017/S1742758412000070

Garfield E (2004) Historiographic mapping of knowledge domains literature. J Inf Sci 30:119-145. https://doi.org/10.1177/0165551504042802

Grimaldi DA, Engel MS (2005) Evolution of the Insects. Cambridge University Press, Cambridge, UK

Kahuthia-Gathu R, Nyambo B, Subramanian S (2017) Impact of introduced parasitoid Cotesia vestalis (Hymenoptera: Braconidae) on Plutella xylostella (Lepidoptera: Plutellidae) and its parasitoid guild on kale in semi-arid areas in Kenya. Int J Trop Insect Sci 37:163-175. https://doi.org/10.1017/S1742758417000091

Kelemu S (2015) A Milestone to Consider: A Note from the Editor-inChief on the First Impact Factor for the International Journal of
Tropical Insect Science (IJT). Int J Trop Insect Sci 35:152. https:// doi.org/10.1017/S1742758415000181

Kessler, (1963) Kessler-1963-American_Documentation. Am Doc 14:10-25

Korir JK, Affognon HD, Ritho CN et al (2015) Grower adoption of an integrated pest management package for management of mango-infesting fruit flies (Diptera: Tephritidae) in Embu, Kenya. Int J Trop Insect Sci 35:80-89. https://doi.org/10.1017/ S1742758415000077

Lee S, Bozeman B (2005) The impact of research collaboration on scientific productivity. Soc Stud Sci 35:673-702. https://doi.org/ 10.1177/0306312705052359

Leone Sciabolazza V, Vacca R, McCarty C (2020) Connecting the dots: implementing and evaluating a network intervention to foster scientific collaboration and productivity. Soc Networks 61:181-195. https://doi.org/10.1016/j.socnet.2019.11.003

Lezama-Gutiérrez R, Molina-Ochoa J, Chávez-Flores O et al (2012) Use of the entomopathogenic fungi Metarhizium anisopliae, Cordyceps bassiana and Isaria fumosorosea to control Diaphorina citri (Hemiptera: Psyllidae) in Persian lime under field conditions. Int J Trop Insect Sci 32:39-44. https://doi.org/10.1017/ S1742758412000069

Liang TP, Liu YH (2018) Research Landscape of Business Intelligence and Big Data analytics: A bibliometrics study. Expert Syst Appl 111:2-10. https://doi.org/10.1016/j.eswa.2018.05.018

Loko YLE, Medegan Fagla S, Kassa P et al (2020) Bioactivity of essential oils of Cymbopogon citratus (DC) Stapf and Cymbopogon nardus (L.) W. Watson from Benin against Dinoderus porcellus Lesne (Coleoptera: Bostrichidae) infesting yam chips. Int J Trop Insect Sci. https://doi.org/10.1007/s42690-020-00235-3

Luukkonen T, Persson O, Sivertsen G (1992) Understanding Patterns of International Scientific Collaboration. Sci Technol Hum Values 17:101-126. https://doi.org/10.1177/016224399201700106

MacNeil C (2019) "One is the loneliest number"; are we witnessing the death throes of the single-author research paper in the field of biological invasions? Manag Biol Invasions 10:1-5. https://doi. org/10.3391/MBI.2019.10.1.01

Makkar GS, Bhatia D, Suri KS, Kaur S (2019) Insect resistance in Rice (Oryza sativa L.): overview on current breeding interventions. Int J Trop Insect Sci 39:259-272. https://doi.org/10.1007/ s42690-019-00038-1

McKelvey JJ (1980) Preface. Int J Trop. Insect Sci 1:v. https://doi.org/ $10.1017 / \mathrm{S} 1742758400000035$

Mudereri BT, Kimathi E, Chitata T, Moshobane MC, Abdel-Rahman EM (2021) Landscape-scale biogeographic distribution analysis of the whitefly, Bemisia tabaci (Gennadius, 1889) in Kenya. Int J Trop Insect Sci 41(2):1585-1599. https://doi.org/10.1007/ s42690-020-00360-Z

Müller SM, Mueller GF, Navarini AA, Brandt O (2020) National publication productivity during the COVID-19 pandemic-a preliminary exploratory analysis of the 30 countries most affected. Biology (basel) 9:1-12. https://doi.org/10.3390/biology9090271

Musundire R, Zvidzai CJ, Chidewe C et al (2014) Nutrient and anti-nutrient composition of Henicus whellani (Orthoptera: Stenopelmatidae), an edible ground cricket, in south-eastern Zimbabwe. Int J Trop Insect Sci 34:223-231. https://doi.org/ $10.1017 /$ S1742758414000484

Muvea AM, Waiganjo MM, Kutima HL et al (2014) Attraction of pest thrips (Thysanoptera: Thripidae) infesting French beans to coloured sticky traps with Lurem-TR and its utility for monitoring thrips populations. Int J Trop Insect Sci 34:197-206. https://doi. org/10.1017/S174275841400040X

Odhiambo TR (1980) Foreword. Int J Trop. Insect Sci 1:vii. https://doi. org/10.1017/S1742758400000047

Olotu MI, Maniania NK, Ekesi S et al (2013) Effect of fungicides used for powdery mildew disease management on the African 
weaver ant, Oecophylla longinoda (Hymenoptera: Formicidae), a biocontrol agent of sap-sucking pests in cashew crops in Tanzania. Int J Trop Insect Sci 33:283-290. https://doi.org/10.1017/ S1742758413000313

Prieto-Gutierrez JJ, Segado-Boj F (2019) Annals of Library and Information Studies: Bibliometric Analysis of the Journal and a Comparison with the Top Library and Information Studies Journals in Asia and Worldwide (2011-2017). Ser Libr. https://doi.org/10. 1080/0361526X.2019.1637387

Pyšek P, Hulme PE, Simberloff D et al (2020) Scientists' warning on invasive alien species. Biol Rev. https://doi.org/10.1111/brv.12627

Ravikumar S, Agrahari A, Singh SN (2015) Mapping the intellectual structure of scientometrics: a co-word analysis of the journal Scientometrics (2005-2010). Scientometrics 102:929-955. https:// doi.org/10.1007/s11192-014-1402-8

Rawlings CM, McFarland DA (2011) Influence flows in the academy: Using affiliation networks to assess peer effects among researchers. Soc Sci Res 40:1001-1017. https://doi.org/10. 1016/j.ssresearch.2010.10.002

Roy S, Ahmed R, Sanyal AK et al (2020) Biodiversity of soil arthropods with emphasis on oribatid mites in three different tea agro-ecosystem with three different agronomical practices in Assam. Int J Trop Insect Sci, India. https://doi.org/10.1007/ s42690-020-00315-4

Saha D, Mukhopadhyay A (2013) Insecticide resistance mechanisms in three sucking insect pests of tea with reference to North-East India: An appraisal. Int J Trop Insect Sci 33:46-70

Saha D, Roy S, Mukhopadhyay A (2012) Insecticide susceptibility and activity of major detoxifying enzymes in female Helopeltis theivora (Heteroptera: Miridae) from sub-Himalayan tea plantations of North Bengal, India. Int J Trop Insect Sci 32:85-93. https://doi.org/10.1017/S1742758412000161

Samal RR, Kumar S (2020) Cuticular thickening associated with insecticide resistance in dengue vector, Aedes aegypti L. Int J Trop Insect Sci. https://doi.org/10.1007/s42690-020-00271-z

Seebens H, Bacher S, Blackburn TM et al (2020) Projecting the continental accumulation of alien species through to 2050. Glob Chang Biol 1-13.https://doi.org/10.1111/gcb.15333

Seebens H, Blackburn TM, Dyer EE et al (2017) No saturation in the accumulation of alien species worldwide. Nat Commun 8:1-9. https://doi.org/10.1038/ncomms14435
Snow RW, Craig M, Deichmann U, Marsh K (1999) Estimating mortality, morbidity and disability due to malaria among Africa's nonpregnant population. Bull World Health Organ 77:624-640

Stork NE (1999) Estimating the number of species on Earth. In: Ponder, W and Lunney D (ed) Other 99\%: he conservation and biodiversity of invertebrates. Royal Zoological Soc New South Wales, Taronga Zoo Mos, Mosman NSW, 2088, Australia, p 1+

Tabatabaei-Malazy O, Ramezani A, Atlasi R et al (2016) Scientometric study of academic publications on antioxidative herbal medicines in type 2 diabetes mellitus. J Diabetes Metab Disord 15:1-8. https://doi.org/10.1186/s40200-016-0273-3

Tumuhaise V, Ekesi S, Mohamed SA et al (2015) Pathogenicity and performance of two candidate isolates of Metarhizium anisopliae and Beauveria bassiana (Hypocreales: Clavicipitaceae) in four liquid culture media for the management of the legume pod borer Maruca vitrata (Lepidoptera: Crambidae). Int J Trop Insect Sci 35:34-47. https://doi.org/10.1017/ S1742758414000605

Tzeng J, Lu H, Li WH (2008) Multidimensional scaling for large genomic data sets. BMC Bioinformatics 9:1-17. https://doi.org/ 10.1186/1471-2105-9-179

van Eck NJ, Waltman L (2010) Software survey: VOSviewer, a computer program for bibliometric mapping. Scientometrics 84:523538. https://doi.org/10.1007/s11192-009-0146-3

van Huis A (2003) Insects as Food in sub-Saharan Africa. Int J Trop Insect Sci 23:163-185. https://doi.org/10.1017/S1742758400023572

Vera MT, Oviedo A, Abraham S et al (2014) Development of a larval diet for the South American fruit fly Anastrepha fraterculus (Diptera: Tephritidae). Int J Trop Insect Sci 34:S73-S81. https://doi. org/10.1017/S1742758414000150

Wagner CS, Leydesdorff L (2005) Network structure, self-organization, and the growth of international collaboration in science. Res Policy 34:1608-1618. https://doi.org/10.1016/j.respol.2005.08.002

Zupic I, Čater T (2015) Bibliometric Methods in Management and Organization. Organ Res Methods 18:429-472. https://doi.org/ $10.1177 / 1094428114562629$

Publisher's Note Springer Nature remains neutral with regard to jurisdictional claims in published maps and institutional affiliations. 